\title{
Clinical presentation of parvovirus B19 infection in HIV-infected patients with and without AIDS
}

\author{
Manifestações clínicas da infecção por parvovírus B19 em \\ pacientes HIV-positivos com e sem AID S
}

\author{
Sérgio Setúbal', Maria Cristina Jorge-Pereira², Anadayr Leite Martins de Sant'Anna², \\ Solange Artimos de Oliveira1, Anna Ricordi Bazin \\ and Jussara Pereira do Nascimento ${ }^{3,4}$
}

\begin{abstract}
Human parvovirus B19 replicates in erythrocyte precursors. Usually, there are no apparent hematological manifestations. However, in individuals with high erythrocyte turnover, as in patients with sicklecell disease and in the fetus, the infection may lead to severe transient aplasia and hydrops fetalis, respectively. In AIDS patients, persistent infection may result in chronic anemia. By contrast, in HIV-positive patients without AIDS the infection evolves as a mild exanthematous disease. Two clinical descriptions exemplify these forms of presentation. In the first, an AIDS patient presented with bone marrow failure that responded to immunoglobulin. In the second, an HIV-positive patient without AIDS had a morbilliform rash, and needed no treatment. Knowing that an AIDS patient has chronic B19 anemia lessens concern about drug anemia; protects the patient from invasive diagnostic maneuvers; and prevents the patient from disseminating the infection. In AIDS patients with pure red cell aplasia, a search for parvovirus B19 DNA in the serum or in the bone marrow is warranted.
\end{abstract}

Key-words: Erythema infectiosum. Sickle cell anemia. Parvovirus. Pure red cell aplasia. AIDS.

Resumo O parvovírus B19 replica-se em precursores eritróides. Não há geralmente manifestações hematológicas aparentes. Entretanto, nas altas taxas de reposição de eritrócitos, como as que ocorrem na anemia falciforme ou no feto, a infecção pode resultar, respectivamente, em aplasia transitória e hidropisia fetal. Em pacientes com AIDS, a infecção persistente pode resultar em anemia crônica. Já num paciente HIVpositivo sem AIDS, a infecção evolui como uma doença exantemática leve. Duas descrições exemplificam estas diferentes modalidades de apresentação clínica. Na primeira, um paciente com AIDS apresentou aplasia medular que respondeu a imunoglobulina. Na segunda, um paciente HIV-positivo sem AIDS apresentou um exantema morbiliforme, que cedeu sem tratamento. Diagnosticar a anemia crônica por B19 diminui as preocupações infundadas sobre anemia por drogas, evita que o paciente seja submetido a manobras diagnósticas invasivas, e impede que o paciente dissemine a infecção. Em pacientes com AIDS acometidos de aplasia eritrocítica pura, está indicada a pesquisa de DNA do parvovírus B19 no soro ou na medula óssea.

Palavras-chaves: Eritema infeccioso. Anemia falciforme. Parvovírus. Aplasia eritrocítica pura. AIDS.

Parvovirus B19 replicates in erythrocyte precursors. Because of the rapid development of an immune response, parvovirus B19 infection is self-limited in most individuals, resolving with rash, arthropathy or no symptoms at all. In most cases there are no clinically expressed hematological manifestations. In individuals with high erythrocyte turnover, however, parvovirus B19 infection may be critical, as may occur in patients with sickle-cell disease (transient aplasia) and in the fetus (hydrops fetalis) ${ }^{3}$. In AIDS patients persisting B19 infection due to impaired immunity may, as it approaches or exceeds the normal red cell life span, result in anemia. This anemia is not as severe as that resulting from transient aplastic crisis in sickle-cell disease but may last months or even years, and be confused with other anemias that may complicate the course of AIDS. The clinical picture is one of bone marrow failure or hypoplasia and is usually restricted to the erythrocytic

\footnotetext{
1. Departamento de Medicina Clínica da Universidade Federal Fluminense, Niterói, RJ, 2. Instituto Estadual de Hematologia Arthur de Siqueira Cavalcanti, Rio de Janeiro, RJ. 3. Departamento de Desenvolvimento Tecnológico, BioManguinhos da Fundação Oswaldo Cruz. 4. Departamento de Microbiologia e Parasitologia da Universidade Federal Fluminense, Rio de Janeiro, RJ.

This work was supported by grants from FAPERJ, CNPq and the British Council.

Address to. Dr. Sérgio Setúbal. R. Gavião Peixoto 112/1002, Icaraí, 24230-101 Niterói, RJ, Brazil.

e-mail: labutes@attglobal.net

Recebido para publicação em 17/6/2002.
} 
lineage (acquired pure red cell aplasia). In HIV-positive patients without AIDS, by contrast, B19 infection evolves as an exanthematous disease, or may be entirely asymptomatic. Descriptions of persistent anemia due to $\mathrm{B} 19$ infection in AIDS patients are plentiful ${ }^{34}$ but there are fewer accounts ${ }^{9}$ of exanthematous disease or asymptomatic infection in HIV positive patients without AIDS. The dual presentations of B19 infection in HIV carriers are exemplified in the two clinical descriptions that follow.

\section{CASE REPORTS}

Case 1. AIDS patient. This patient, a 32-year-old white HIV-positive male, presented in November 1994 with tiredness for five months, attributed to chronic exposure to insecticides. He had been working for seven years as a sanitary agent. He was a heavy drinker and smoker, and reported intravenous drug use. He denied homosexual relations, but reported unprotected sex with many partners. He had a hematocrit of $23 \%$ and a hemoglobin concentration of $7.5 \mathrm{~g} / \mathrm{dl}$. A bone marrow aspirate showed overall hypocellularity, with a myeloid/ erythroid ratio of 9:1. The diagnosis was bone marrow failure due to chemical hazard and the patient, after being transfused five times with no improvement, was referred from his hometown to the Instituto de Hematologia Arthur de Siqueira Cavalcanti, in Rio de Janeiro.

He was admitted there on January 1st, 1995, with a temperature of $39^{\circ} \mathrm{C}$ and a parotid abscess. He was anemic and toxemic, but showed no signs of body wasting. He soon became well on oxacillin treatment, but continued to need transfusions. He was anti-HCV positive and had a CD4 count of $32 / \mathrm{mm}^{3}$. The viral load was not measured. The diagnosis was auto-immune hemolytic anemia due to HIV virus, and he was started on prednisone, 40mg PO qd. On January 19th a peripheral blood dot blot ${ }^{8}$ and $\lg G$ antibody test ${ }^{12}$ were both positive for parvovirus B19. A new bone marrow biopsy confirmed previous findings. He was discharged for follow-up, with complete regression of his parotid swelling, but still anemic and tired. Despite his anemia, he started zidovudine and sulfamethoxazoletrimethoprim in February 1995. The peripheral blood parvovirus dot blot and IgG test were repeated in April 1995 and were again found positive. He was readmitted in May 1995 for specific treatment with intravenous human immunoglobulin, $400 \mathrm{mg} / \mathrm{kg} /$ day for seven days. A third bone marrow biopsy revealed erythroid and myeloid hypoplasia, as well as reticulinic fibrosis. The patient showed improvement after immunoglobulin treatment (Figure 1). Didanosine was added to the zidovudine treatment. Another course of immunoglobulin was planned, but it could not be obtained and given until June 1996. At that time he greatly improved and was discharged to be followed as an outpatient. In August 1996 new B19 peripheral blood dot blot and anti-B19 IgG tests were again positive, but not so strongly as before. He remained well until June 1997, when lost to follow-up.

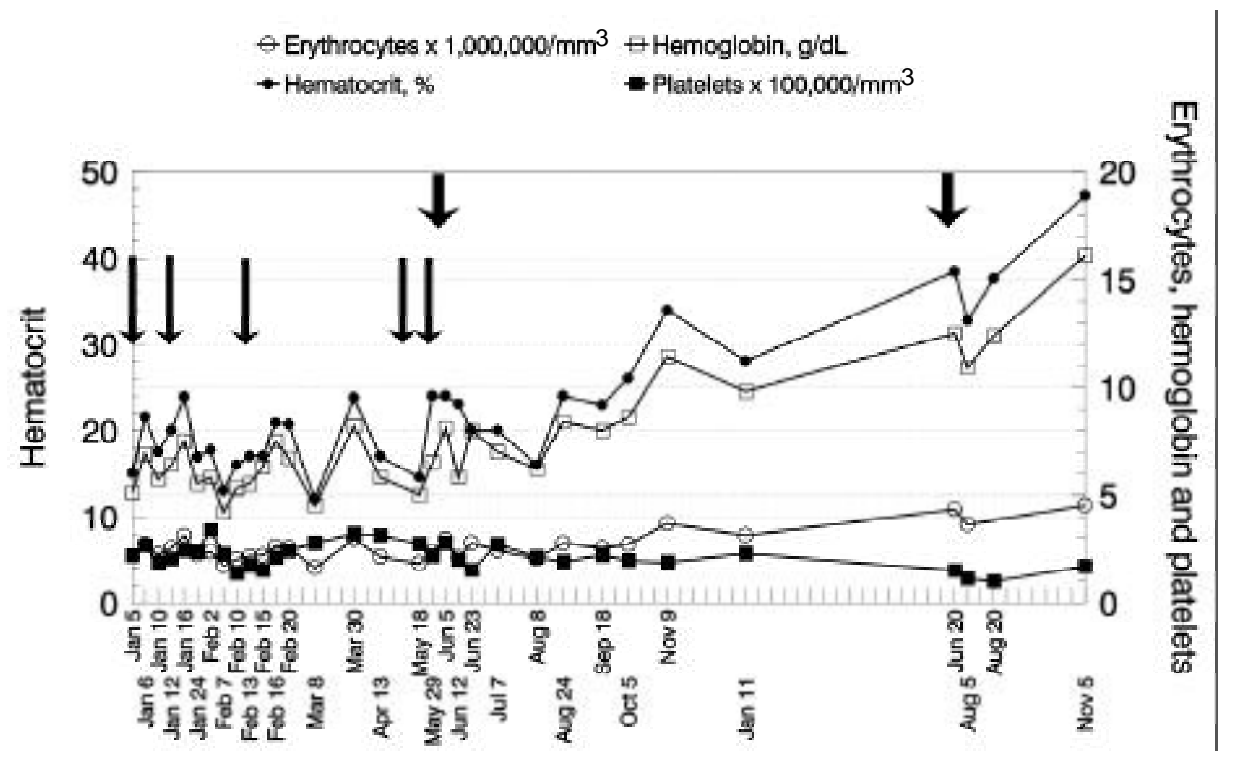

Short arrows. Immunoglobulin infusions. Long arrows. Packed red cells transfusions.

Figure 1 - Evolution of patient 1. 
Case 2. HIV patient without AIDS defining conditions. This patient, a 36-year-old white male homosexual, presented on August 6,1999, with a morbilliform rash and mild pruritus. The rash began six days before presentation, having started on the trunk and spreading afterwards over the trunk and limbs, involving the palms, soles and, less intensely, the face. There was also a temperature exceeding $38.5^{\circ} \mathrm{C}$ and arthritis. There was no cough or nasal discharge, but the patient reported pharyngitis and conjunctivitis. These had already subsided on presentation and there were neither myalgias nor lymphadenitis. The rash did not desquamate and was not hemorrhagic. The patient was given symptomatic therapy and returned to work in less than a week, with a fading rash and a provisional diagnosis of non-specified exanthema. A serum sample obtained on presentation was reactive for IgM and IgG antibodies $^{12}$ to parvovirus B19. This sample was not reactive for acute rubella, dengue or measles. Viremia (B19 DNA dot blot) could not be demonstrated. No blood count was obtained on presentation. A VDRL test was done subsequently and was negative. The patient was taking zidovudine $(600 \mathrm{mg}$ bid) and zalcitabine $(0.75 \mathrm{mg}$ tid) for established HIV infection. His last CD4 count was $468 / \mathrm{mm}^{3}$, with a viral load of $14.000 / \mathrm{ml}^{3}$, on November 1998. He had never had an AIDS defining disease. His blood counts were unexceptional, except for a relatively low hematocrit in January 1999 and the increased medium corpuscular volume commonly observed in patients taking zidovudine. This patient was among an HIV-positive cohort followed by us in a previous study ${ }^{1}$, in which he had been repeatedly found reactive for serum IgG against parvovirus B19. On that occasion (November 1997) his serum dot blot and IgM against parvovirus B19 were both negative. His lowest CD4 count was $374 / \mathrm{mm}^{3}$ on May 1995 (viral load not available at this time).

\section{DISCUSSION}

The diagnosis of parvovirus B19 infection may be difficult in immunodeficient patients. Although $\lg G$ and $\lg M$ antiparvovirus B19 antibodies may be more prevalent in AIDS patients than in the general population ${ }^{11}$, in AIDS patients with pure red cell aplasia anti-B19 antibodies may be undetectable or show only weak IgM titers. The inconstant humoral response may preclude the serologic diagnosis in this setting, compelling to the use of more sophisticated diagnostic methods, such as PCR, in situ hybridization, dotblot, and, notwithstanding its lower sensitivity, immunohistochemistry with monoclonal antibodies ${ }^{4}$.

The above does not necessarily apply to HIV-positive patients with normal or near normal immune responses, in whom a serologic diagnosis is frequently possible. Erythema infectiosum and/or the articular syndrome normally accompanying parvovirus B19 infection are thought to be due to immune complex depositions in vessels and synovia ${ }^{4}$ and once the patient has produced antibodies, these symptoms ensue. The appearance of the same symptoms after human immunoglobulin administration to immunodeficient patients with hitherto asymptomatic B19 infection is consistent with this ${ }^{4}$. The diagnosis in our second patient was a serologic one. We could not find an explanation for the previous presence of IgG against B19 almost two years earlier. Perhaps, despite his good CD4 counts, the patient already had some kind of immunologic impairment and it is possible to have a persistent B19 infection with delayed clinical manifestations. Musiani and colleagues ${ }^{9}$ described two HIV-positive patients with persistently positive PCR (ascribed to low level viremia) and one of them was PCR positive two years before the onset of an aplastic crisis and the other seven months before the onset of an illness similar to fifth disease. Antibody assays for B19 were not done, however. The HIV infections in these patients were described as grade II (asymptomatic), according to the CDC 1987 classification system, but they both progressed to grade IV during the observation period. It is not clear at what stage in this progression have they developed B19related clinical manifestations. It is also possible to have B19 IgG antibodies prior the detection of B19 viremia, as was the case in one HIV positive patient prospectively followed by Goedert and colleagues ${ }^{5}$. He had IgG B19 antibodies some three years before developing a positive nested PCR for B19 DNA in the serum. It is impossible to exclude the passive acquisition of antibodies by blood transfusion. The PCR reaction turned to negative, but the patient remained IgG positive.

The diagnosis of B19 infection may also be hinted at by the histopathological aspect of bone marrow: overall hypocellularity, and the presence of giant pronormoblasts with finely granulated cytoplasm and glassy, variably eosinophilic, intranuclear inclusions with a clear central halo (lantern cells) are thought to be indicative of parvovirus B19 infection ${ }^{6}$. These giant pronormoblasts were not described in our first patient, whose diagnosis resulted from the systematic dot-blot testing of persistently anemic AIDS patients.

Despite the difficulties, the diagnosis of chronic B19 anemia in AIDS patients is important for several reasons: 1) it lessens concerns about zidovudine associated anemia; 2) it prevents the patient being submitted to invasive maneuvers aimed to clarify the causes of the anemia; and 3) it prevents the patient from disseminating the infection to other immunodeficient patients (with whom he or she may associate in wards and outpatient sectors) or to pregnant women at home ${ }^{4}$. The presence of pure red cell aplasia in an AIDS patient, (specially when accompanied with compatible bone marrow pathological findings) warrants a laboratory search for B19 infection, for intravenous immunoglobulin therapy is expensive and should not be used simply on an empirical basis or as a therapeutic test. Also, the effect 
of some therapies used to treat anemia in AIDS patients, e.g., erythropoietin ${ }^{2}$, can be harmful in B19-infected patients, as they may increase the substrate for viral replication. Other drugs, such as the corticosteroids given to our first patient, can also be dangerous in the long run, as they may enhance immunodeficiency. In AIDS patients with pure red cell aplasia not otherwise explained, a search for parvovirus B19 DNA in the serum must be done through dot-blot and PCR, or in the bone marrow through immunohistochemistry or in situ hybridization?

Treatment can be with intravenous standard human immunoglobulin, which generally has sufficient antibodies to clear viremia ${ }^{4}$. It is used in doses of $400 \mathrm{mg} / \mathrm{kg}$ qd over 1 to 5 days. This can be repeated in case of relapse. Patients with CD4 counts over $300 / \mathrm{mm}^{3}$ tend to have sound responses, without relapses. More immunodeficient patients usually relapse, and need repeated therapy, or suppressive prophylaxis ${ }^{366}$. It seems to have been the case with our first patient, who only had a partial response after the first course of treatment, and needed another one. Reconstitution of immunity by HAART can also lead to resolution of anemia ${ }^{10}$.

In short, HIV patients with unimpaired immunity are likely to manifest their parvovirus B19 infection as an exanthematic or joint disease, without hematologic involvement. In HIV patients with more advanced immunodeficiency, there may be persistent anemia and no rash.

\section{ACKNOWLEDGEMENTS}

The authors would like to thank Dr. Philip Mortimer for reviewing the text.

\section{REFERENCES}

1. Aguiar FS, Lopes DP, Bazin AR, Setúbal S, Cohen BJ, Nascimento JP. Human parvovirus B19 infection in HIV-positive patients. Revista da Sociedade Brasileira de Medicina Tropical 34: 239-242, 2001.

2. Borkowski J, Amrikachi M, Hudnall SD. Fulminant parvovirus infection following erythropoietin treatment in a patient with acquired immunodeficiency syndrome. Archives of Pathology \& Laboratory Medicine 124: 441-445, 2000.

3. Brown KE, Young NS. Human Parvovirus B19: Pathogenesis of Disease. In: Anderson LJ, Young NS (eds) Human Parvovirus B19. Monographs in Virology, Basel, Karger, volume 20, 1997.

4. Frickhofen N, Abkowitz JL, Safford M, Berry JM, Antunez-deMayolo J, Astrow A, Cohen R, Halperin I, King L, Mintzer D, Cohen B, Young NS. Persistent B19 parvovirus infection in patients infected with human immunodeficiency virus type 1 (HIV-1): a treatable cause of anemia in AIDS. Annals of Internal Medicine 113: 926-933, 1990.

5. Goedert JJ, Erdman DD, Konkle BA, Török TJ, Lederman MM, Kleinert D, Mandalaki T, Kessler CM, Anderson LJ, Luban NLC. Parvovirus B19 quiescence during the course of Human Immunodeficiency Virus Infection in persons with hemophilia. American Journal of Hematololgy 56: 248-251, 1997.

6. Koduri PR. Novel cytomorphology of the giant proerythroblasts of parvovirus B19 infection. American Journal of Hematology 58: 95-99, 1998.
7. Koduri PR, Kumapley R, Valladares J, Teter C. Chronic pure red cell aplasia caused by parvovirus B19 in AIDS: use of intravenous immunoglobulin, a report of eight patients. American Journal of Hematology 61: 16-20, 1999.

8. Mori J, Field AJ, Clewley JP, Cohen BJ. Dot blot hybridization assay of B19 virus DNA in clinical specimens. Journal of Clinical Microbiology 27: 459-464, 1989.

9. Musiani M, Zerbini G, Gentilomi G, Rodorigo G, De Rosa V, Gibellini D, Venturoli S, Gallinella G. Persistent B19 Parvovirus Infections in Haemophilic HIV-1 Infected Patients. Journal of Medical Virology 48: 103-108, 1995.

10 Mylonakis E, Dickinson BP, Mileno MD, Flanigan T, Schiffman FJ, Mega A, Rich JD. Persistent parvovirus B19 related anemia of seven years duration in an HIV-infected patient: complete remission associated with highly active antiretroviral therapy. American Journal of Hematolology 60: 164-166, 1999.

11. Nigro G, Luzi G, Fridell E, Ferrara M, Pisano P, Gattinara GC, Mezzaroma I, Soderlund M, Rasnoveanu D, Aiuti F. Parvovirus infection in children with AIDS: high prevalence of B19-specific immunoglobulin $M$ and $G$ antibodies. AIDS 6: 679-684, 2002.

12. Pereira RFA, Paula WNS, Cubel RCN, Nascimento JP. Anti-VP1 and anti-VP2 antibodies detected by immunofluorescence assays in patients with acute human parvovirus B19 infection. Memórias do Instituto Oswaldo Cruz 96: 507-513, 2001. 